\title{
Efficacy of Different Oil-Cakes as Soil Amendment for the Management of Root-knot Nematode, Meloidogyne incognita Infecting Okra (Abelmoschus esculentus L.)
}

\author{
B. L. Baheti, S. S. Bhati* and Hanuman Singh \\ Department of Nematology, Rajasthan College of Agriculture (MPUAT), Udaipur \\ (Rajasthan), India \\ College of Agriculture (Agriculture University, Jodhpur), Nagaur (Rajasthan), India \\ *Corresponding author
}

\section{A B S T R A C T}

\section{Keywords}

Management,

Meloidogyne

incognita, Oil cakes and Okra

\section{Article Info}

Accepted:

xx November 2019

Available Online:

xx December 2019
Okra [Abelmoschus esculentus (L.) Moench.] is an important vegetable crop grown in tropical and subtropical regions of the world. The production of okra suffers from number of pest and pathogens including nematodes. Amongst nematodes, root-knot nematode, Meloidogyne incognita is most important and responsible to cause significant economic losses in worldwide due to favorable soil and environmental conditions. In present investigation neem, karanj and mustard oil-cakes have been tested for the management of root-knot nematode, $M$. incognita infecting okra on farmer's field naturally infested with test nematode. These were applied @ 2, 4 and 6 q/ha maintaining chemical treated (carbofuran $2 \mathrm{~kg}$ a.i./ha) and untreated control for comparing the experimental results. The observations on number of galls/plant, egg masses/plant, eggs and larvae/egg mass, final nematode population/100 $\mathrm{cc}$ soil and yield were recorded. Results showed that neem cake @6 q/ha was proved to be most effective for the management of $M$. incognita on okra while karanj cake @ $6 \mathrm{q} / \mathrm{ha}$ was found best to enhanced crop yield (49.18-53.51\%) followed by neem cake @ $6 \mathrm{q} / \mathrm{ha}$ (40.98-45.61\%) and karanj cake @ 4 q/ha (39.34-43.86 \%) over untreated control. Higher yield was obtained with the application of karnaj cake@ $6 \mathrm{q} / \mathrm{ha}$ as compared to carbofuran @ $2 \mathrm{~kg}$ a.i./ha during both the years.

\section{Introduction}

The okra [Abelmoschus esculentus (L.) Moench.] or lady's finger also known as "Bhindi" is an annual vegetable crop grown in tropical and subtropical parts of the world. It belongs to family- Malvaceae and suitable for cultivation as a garden crop as well as on large commercial farms. It is mainly grown in India, Turkey, Iran, Western Africa, Yugoslavia, Bangladesh, Afghanistan, Pakistan, Burma, Japan, Malaysia, Brazil, Ghana, Ethiopia, Cyprus and U.S.A. It is cultivated throughout the country in different seasons mainly in 
rainy and summer. The major okra producing states are Andhra Pradesh, Bihar, Orissa, Gujarat, West Bengal, Assam, Rajasthan, Madhya Pradesh, Utter Pradesh and Karnataka. It is grown in 528.54 thousand hectares of area with production of 6146.69 thousand million tones and productivity of 11.64matric tones /ha in India (Anonymous, 2018-19a). In Rajasthan, it is cultivated mainly in Ajmer, Alwar, Jaipur, Kota, Bundi, Chittorgarh, Bhilwara, Rajsamand, Jhalawar, Dausa, Sriganganagar, Jodhpur, Pali, Sirohi, Banswara, Pratapgarh and Udaipur districts in the area of 3.40 thousand hectares with production of 10.50thousand million tones and productivity of 3.08 matric tones /ha (Anonymous, 2018-19b).

Okra is high nutritious vegetable and is a rich source of potassium, calcium, magnesium, phosphorus, vitamin ' $A$ ' and ' $C$ '. The nutritional value of $100 \mathrm{~g}$ edible okra is composed of $1.9 \mathrm{~g}$ protein, $0.2 \mathrm{~g}$ fat, $6.4 \mathrm{~g}$ carbohydrate, $0.7 \mathrm{~g}$ minerals, $89.6 \mathrm{~g}$ moisture, 88.01 I.V. vitamin A, $0.07 \mathrm{mg}$ thiamine, 13.0 $\mathrm{mg}$ vitamin $\mathrm{C}, 0.1 \mathrm{mg}$ riboflavin, $1.5 \mathrm{mg}$ iron, $1.2 \mathrm{~g}$ fibers and other nutrients. Apart from its high vitamin B and folic acid contents, it is said to be very useful against genitor-urinary disorder, spermatorrahoe and chronic dysentery. It is also used in curing ulcers and hemorrhoids. The mucilage powder of root and stem of okra is very effective in the clarification of sugarcane juice which is used in the preparation of gur, brown sugar and jaggary. The fully ripen fruits and stem containing crude fiber are used in the paper and cosmetic industry.

The crop of such an economic importance is suffered from several biotic and abiotic factors. Among biotic factors, insect pests (fruit borer, white fly, jassids etc.) and diseases (yellow vein mosaic, powdery mildew etc.) are the most important ones including plant parasitic nematodes. Plant parasitic nematodes viz., Meloidogyne spp.,
Pratylenchus spp., Rotylenchulus reniformis, Tylenchorhynchus spp., Hoplolaimus spp., Helicotylenchus spp. and Xiphinema spp. have been found associated with okra in India (Mahajan and Kaur, 1991; Ravichandra and Krishnappa, 2004; Srivastava et al., 2012). Among nematodes, root-knot nematode (Meloidogyne spp.) is considered as most important pest of okra and farmers experience chronic losses because of high frequency and distribution of this nematode in all agroclimatic zones of India (Prasad, 1960; Yadav et al., 1969 and Parvatha Reddy, 1986).

In India, root-knot nematode was first reported by Barber (1901) on tea roots from Devala territory of Kerala. In Rajasthan, Arya (1957) reported root-knot nematode on tomato from Jodhapur. Bhatti and Jain (1977) reported yield losses to the extent of $90 \%, 46.2 \%$ and $23 \%$ in okra, tomato and brinjal by root-knot nematode, Meloidogyne incognita under field conditions in Haryana. Parvatha Reddy and Singh (1981) reported losses to the extent of 28.08 per cent in okra, 33.68 per cent in brinjal, 43.48 per cent in french bean, 28.60 per cent in cowpea and 20.00 per cent in peas due to root-knot nematode, Meloidogyne incognita. Sharma and Baheti (1992) reported losses to the tune of 46.0, 46.7, 47.8 and $55.4 \%$ on pea, okra, tomato and bottle gourd, respectively by root-knot nematode, $M$. incognita and $M$. javanica under light soil of Rajasthan. Baheti and Bhati (2017) reported that avoided yield losses to the tune of 41.30$45.50 \%, 37.50-41.52 \%$ and $22.45-25.38 \%$ in light, medium and heavy soils, respectively caused by $M$. incognita on okra.

\section{Materials and Methods}

Organic amendments play an important role in management of plant parasitic nematodes. With this view, trial was conducted to test the efficacy of neem (Azadirachta indica), karanj (Pongamia pinnata) and mustard (Brassica campestris) cakes for the management of root- 
knot nematode, $M$. incognita on okra at farmers field during two consecutive years. Oil-cakes were applied @ 2, 4 and 6 q/ha as row application. A standard chemical check (carbofuran $2 \mathrm{~kg}$ a.i./ha) and untreated check was also maintained. The required quantity of cakes and chemicals were calculated and weighed separately for each plot (10 sq. m.) and mixed well in soil at the time of sowing. Soil samples were collected to estimate the initial nematode population. The experiment was laid out in randomized block design with five replications. Okra variety "Parbhani Kranti" was sown with dibbling method. All agronomical practices were adopted throughout the cropping period. Observations viz., number of galls/plant, egg masses/plant, eggs and larvae/egg mass, final nematode population/100 cc soil and yield/plot were taken for comparison of treatments. Then, data were compiled and analyzed for interpretation of findings.

\section{Results and Discussion}

Organic amendments bring about changes in physical properties of soil like water holding capacity, soil texture, structure, aeration etc. In addition, they are reported to enhance host vigor by providing macro and micro nutrients, increases the activity of beneficial soil microbes (nematophagous fungi, bacteria etc.) and releases some sort of toxins which adversely affects the life cycle processes of phytonematodes (Singh and Sitaramaiah, 1970). Amendment of soil with oil-cakes such as neem, karanj, mahua, castor, mustard, cotton, etc. have shown tremendous potential with regards to nematode management and crop yield (Devi and Das, 2016; Sahu et al.,2018).

Looking to the attributes of organic amendment with oil-cakes, in present investigation neem, karanj and mustard oilcakes have been tested for the management of root-knot nematode, $M$. incognita infecting okra on farmer's field naturally infested with test nematode. These were applied @ 2,4 and $6 \mathrm{q} / \mathrm{ha}$ maintaining chemical treated (carbofuran $2 \mathrm{~kg}$ a.i./ha) and untreated control for comparing the experimental results. The observations on number of galls/plant, egg masses/plant, eggs and larvae/egg mass, final nematode population/100 cc soil and yield were recorded and presented in Table 1 and 2.

\section{Galls per plant}

Results revealed that number of galls per plant reduced with the organic amendment of oilcakes over untreated control during both the year I and II on okra. Among different oilcakes, neem cake when applied at $6 \mathrm{q} / \mathrm{ha}$ was found to be best and produced minimum galls (51.60 and 58.00) followed by karanj cake at 6 $\mathrm{q} / \mathrm{ha}$ (55.20 and 60.00) and neem cake at 4 q/ha (56.80 and 64.20) over untreated control (85.00 and 95.80) during both the cropping year. However, soil application of carbofuran at $2 \mathrm{~kg}$ a.i./ha (46.40 and 49.60) was found significantly better overall oil-cakes tested with regards to reducing galls produced by $M$. incognita on okra. It has been observed that all the treatments significantly reduced galls over untreated control.

Results presented in Table 1 showed that application of neem cake @ 6 q/ha reduces galls to the tune of 39.29 and $39.46 \%$ whereas in karanj cake @6 q/ha and neem cake @ 4 q/ha, it was estimated to be 35.06 and $37.37 \%$ and 33.18 and $32.99 \%$, respectively over untreated control. Maximum reduction (45.41 and $48.23 \%$ ) in galls was noticed with the application of carbofuran at $2 \mathrm{~kg}$ a.i./ha in year I and II, respectively.

Based on Table 2, the trend (Minimum to maximum) in all the treatments was $\mathrm{T} 10>\mathrm{T} 3$ $=\mathrm{T} 6=\mathrm{T} 2=\mathrm{T} 5=\mathrm{T} 9>\mathrm{T} 1=\mathrm{T} 4=\mathrm{T} 8>\mathrm{T} 7>$ $\mathrm{T} 11$ during $\mathrm{I}$ year and $\mathrm{T} 10>\mathrm{T} 3=\mathrm{T} 6=\mathrm{T} 2=$ $\mathrm{T} 9=\mathrm{T} 5>\mathrm{T} 1=\mathrm{T} 8=\mathrm{T} 4>\mathrm{T} 7>\mathrm{T} 11$ during II year, wherein the values statistically non- 
significant have been expressed as "=" (equal).

\section{Egg masses per plant}

Results revealed that organic amendment with oil-cakes reduced egg mass formation of $M$. incognita on okra as compared to untreated control. Among oil-cakes, minimum number of egg masses (31.80 and 34.00) were obtained with the application of neem cake @ 6 q/ha followed by neem cake @ 4 q/ha (37.80 and 39.40) and karanj cake @ 6 q/ha (38.00 and 40.80) over untreated control (57.60 and $61.20)$ during I and II year, respectively. However, carbofuran $2 \mathrm{~kg}$ a.i./ha as soil application at the time of sowing was found most effective in reducing egg masses (27.80 and 30.00) on okra and was found significantly better over neem cake @ 6 q/ha. On the whole, all the treatments significantly reduced egg masses over untreated control.

Experimental results exhibited that soil amendment with neem cake @ 6 q/ha decreased egg masses to the tune of 44.79 and $44.44 \%$ over untreated control followed by neem cake @ 4 q/ha (34.38 and 35.62\%) and karanj cake@6 q/ha (34.03 and $33.33 \%)$ during I and II year, respectively. Maximum reduction (51.74 and $50.98 \%$ ) in egg masses was obtained with the application of carbofuran@2 kg a.i./ha.

Based on Table 2, the order (Minimum to maximum) in all the treatments was T10> T3> $\mathrm{T} 2=\mathrm{T} 6>\mathrm{T} 5=\mathrm{T} 1=\mathrm{T} 9=\mathrm{T} 8=\mathrm{T} 4>\mathrm{T} 7>\mathrm{T} 11$ during $\mathrm{I}$ year and $\mathrm{T} 10>\mathrm{T} 3>\mathrm{T} 2=\mathrm{T} 6=\mathrm{T} 9=$ $\mathrm{T} 5=\mathrm{T} 1>\mathrm{T} 8=\mathrm{T} 4>\mathrm{T} 7>\mathrm{T} 11$ during II year, wherein statistically non-significant values have been expressed as "=" (equal).

\section{Eggs and larvae per egg mass}

Experimental findings showed that contents of egg masses on okra reduce with the oil-cake amendments over untreated control during I and II year. However, among different oilcakes, minimum eggs and larvae per egg mass (217.00 and 222.40) was observed in neem cake when applied at $6 \mathrm{q} / \mathrm{ha}$ followed by karanj cake at $6 \mathrm{q} / \mathrm{ha}$ (226.40 and 229.60) and neem cake at $4 \mathrm{q} / \mathrm{ha}$ (228.00 and 232.60) over untreated control (248.40 and 266.00). On the whole, minimum egg mass contents $(195.00$ and 204.00) was obtained with soil application of carbofuran at $2 \mathrm{~kg}$ a.i./ha. The application of chemical significantly decreased eggs and larvae per egg mass over oil-cake amendments including neem cake@6q/ha. These treatments significantly reduced eggs mass contents over untreated control.

Results showed that application of neem cake (a) $6 \mathrm{q} / \mathrm{ha}$ reduced egg mass contents to the tune of 12.64 and $16.39 \%$, whereas, it was 8.86 and $13.68 \%$ and 8.21 and $12.56 \%$ with karanj@6 q/ha and neem cake @ 4 q/ha, respectively over untreated control. Maximum reduction in egg mass contents (21.50 and $23.31 \%$ ) was noted with the application of carbofuran at $2 \mathrm{~kg}$ a.i./ha during I and II year.

Based on Table 2, the trend (Minimum to maximum) in all the treatments was $\mathrm{T} 10>\mathrm{T} 3=\mathrm{T} 6=\mathrm{T} 2=\mathrm{T} 5=\mathrm{T} 9=\mathrm{T} 1=\mathrm{T} 4=\mathrm{T} 8=\mathrm{T} 7=\mathrm{T} 1$ 1 during $\mathrm{I}$ year and $\mathrm{T} 10>\mathrm{T} 3=\mathrm{T} 6=\mathrm{T} 2=\mathrm{T} 5=$ $\mathrm{T} 9=\mathrm{T} 1=\mathrm{T} 8=\mathrm{T} 4=\mathrm{T} 7=\mathrm{T} 11$ during II year, wherein the values statistically non-significant have been expressed as "=" (equal).

\section{Final nematode population}

Results presented in Table 1 revealed that final soil population of root-knot nematode decreased with the oil-cake amendments over untreated control. Among oil-cakes, minimum nematode population (427.60 and 458.20) was recorded with the application of neem cake at $6 \mathrm{q} /$ ha followed by its $4 \mathrm{q} / \mathrm{ha}$ dose (502.00 and 533.60), karanj cake (505.60 and 553.60) and mustard cake at $6 \mathrm{q} / \mathrm{ha}$ dose $(545.40$ and 
588.00) as compared to untreated control (736.00 and 830.00). However, soil application of carbofuran at $2 \mathrm{~kg}$ a.i./ha was found to be the best with respect to reducing final soil population of nematode (411.60 and 430.60) and was at par with neem cake @ $6 \mathrm{q} / \mathrm{ha}$. Significant differences were noticed between $6 \mathrm{q}$ and $4 \mathrm{q}$ dose of neem cake. On the whole, all the treatments significantly decreased final nematode population over untreated control.

Soil amendment with neem cake at $6 \mathrm{q} / \mathrm{ha}$ decreased final soil population of nematode to the tune of 41.90 and $44.80 \%$ over untreated control during I and II year, respectively. It was observed to be 31.79 and $35.71 \%$ (neem cake @ 4 q/ha), 31.30 and $33.30 \%$ (karanj cake @ 6 q/ha), and 25.90 and $29.16 \%$ (mustard cake@6 q/ha). Highest reduction (44.08 and $48.12 \%)$ in nematode population was noticed with application of carbofuran @ $2 \mathrm{~kg}$ a.i./ha.

Based on Table 2, the trend (Minimum to maximum) in all the treatments was $\mathrm{T} 10=$ $\mathrm{T} 3>\mathrm{T} 2=\quad \mathrm{T} 6=\mathrm{T} 9=\mathrm{T} 5=\mathrm{T} 1=\mathrm{T} 8=\mathrm{T} 4=\mathrm{T} 7>\mathrm{T} 11$ during I year and $\mathrm{T} 10=\mathrm{T} 3>\mathrm{T} 2=\mathrm{T} 6=\mathrm{T} 9=$ $\mathrm{T} 5=\mathrm{T} 1>\mathrm{T} 8=\mathrm{T} 4>\mathrm{T} 7>\mathrm{T} 11$ during II year, wherein the values statistically non-significant have been expressed as "=" (equal).

\section{Yield}

Yield of okra was increased with the neem, karanj and mustard oil-cakes when applied @ 2, 4 and $6 \mathrm{q} / \mathrm{ha}$ as soil amendment in root-knot nematode infested field. Among oil-cakes, maximum yield (87.50 and $91.00 \mathrm{q} / \mathrm{ha}$ ) was obtained with the application of karanj cake @ 6 q/ha followed by neem cake @ 6 q/ha $(83.00$ and $86.00 \mathrm{q} / \mathrm{ha})$, karanj cake @ $4 \mathrm{q} / \mathrm{ha}(82.00$ and $85.00 \mathrm{q} / \mathrm{ha}$ ) and mustard cake @ $6 \mathrm{q} / \mathrm{ha}$ ( 80.00 and $83.80 \mathrm{q} / \mathrm{ha})$ as compared to untreated control (57.00 and $61.00 \mathrm{q} / \mathrm{ha})$ during I and II year. Higher yield (85.00 and $88.00 \mathrm{q} / \mathrm{ha}$ ) was also recorded with soil application of carbofuran @ $2 \mathrm{~kg}$ a.i./ha, but it was at par with the karanj cake at $6 \mathrm{q} / \mathrm{ha}$. It was observed that all the treatments significantly enhanced yield of okra over untreated control.

Per cent yield increase over control was also calculated with the application of various treatments to interpret the experimental findings. It was registered highest when karanj cake was applied at $6 \mathrm{q} / \mathrm{ha}$ (53.51 and 49.18 $\%$ ) followed by carbofuran at $2 \mathrm{~kg}$ a.i./ha (49.12 and $44.26 \%$ ), neem cake at $6 \mathrm{q} / \mathrm{ha}$ (45.61 and $40.98 \%$ ), karanj cake at $4 \mathrm{q} / \mathrm{ha}$ (43.86 and $39.34 \%$ ) and mustard cake at 6 q/ha (40.35 and $37.38 \%$ ) during I and II year, respectively over untreated control.

Based on Table 2, the trend (Maximum to minimum) in all the treatments was $\mathrm{T} 6=\mathrm{T} 10=$ $\mathrm{T} 3=\mathrm{T} 5=\mathrm{T} 9=\mathrm{T} 2=\mathrm{T} 4=\mathrm{T} 8=\mathrm{T} 1=\mathrm{T} 7>\mathrm{T} 11$ during $\mathrm{I}$ year and $\mathrm{T} 6=\mathrm{T} 10=\mathrm{T} 3=\mathrm{T} 5=\mathrm{T} 9=$ $\mathrm{T} 2=\mathrm{T} 4=\mathrm{T} 8=\mathrm{T} 1=\mathrm{T} 7>\mathrm{T} 11$ during II year, wherein the values statistically non-significant have been expressed as "=" (equal).

On the whole, soil amendment with neem cake @ 6 q/ha was observed best for the management of root-knot nematode whereas, karnaj cake @ 6 q/ha was proved most effective to enhanced yield of okra.

The results obtained in present investigation are also in accordance with findings of Srivastava et al., (1971), Thakur and Darekar (1995), Ramkrishnan et al., (1997), Patel et al., (1998), Goswami and Singh (1998), Muhammad et al., (2001) and Parihar et al., (2015).

Muhammad et al., (2001) reported that organic amendments of soil with neem cake, mustard cake, farm yard manure and poultry manure at $25 \mathrm{~g} / \mathrm{kg}$ of soil significantly reduced the incidence of $M$. javanica infecting mungbean cv. MNH-92. 
Table.1 Efficacy of different oil-cakes as soil amendment for the management of root-knot nematode, Meloidogyne incognita infecting okra

\begin{tabular}{|c|c|c|c|c|c|c|c|c|c|c|c|c|}
\hline \multirow[t]{2}{*}{ Treatments } & \multicolumn{2}{|c|}{ Galls/ plant } & \multicolumn{2}{|c|}{ Egg masses/ plant } & \multicolumn{2}{|c|}{$\begin{array}{c}\text { Eggs and larvae/ egg } \\
\text { mass }\end{array}$} & \multicolumn{2}{|c|}{$\begin{array}{l}\text { Final nematode } \\
\text { population/ } \\
100 \text { cc soil }\end{array}$} & \multicolumn{2}{|c|}{$\begin{array}{c}\text { Yield } \\
(\mathrm{kg} / \text { plot })\end{array}$} & \multicolumn{2}{|c|}{$\begin{array}{l}\text { Yield } \\
\text { (q/ha) }\end{array}$} \\
\hline & I year & II year & I year & II year & I year & II year & I year & II year & I year & II year & I year & II year \\
\hline $\begin{array}{c}\text { Neem Cake } 2 \text { q/ha } \\
\left(T_{1}\right)\end{array}$ & 66.40 & 74.60 & 41.20 & 44.80 & 235.60 & 246.00 & 548.20 & 608.00 & 7.20 & 7.38 & 72.00 & 73.80 \\
\hline $\begin{array}{c}\text { Neem Cake } 4 \text { q/ha } \\
\left(T_{2}\right)\end{array}$ & 56.80 & 64.20 & 37.80 & 39.40 & 228.00 & 232.60 & 502.00 & 533.60 & 7.92 & 8.23 & 79.20 & 82.30 \\
\hline $\begin{array}{c}\text { Neem Cake } 6 \text { q/ha } \\
\left(T_{3}\right)\end{array}$ & 51.60 & 58.00 & 31.80 & 34.00 & 217.00 & 222.40 & 427.60 & 458.20 & 8.30 & 8.60 & 83.00 & 86.00 \\
\hline $\begin{array}{c}\text { Karanj Cake } 2 \text { q/ha } \\
\left(T_{4}\right)\end{array}$ & 68.00 & 76.20 & 45.00 & 49.20 & 238.00 & 250.00 & 603.00 & 668.80 & 7.65 & 7.82 & 76.50 & 78.20 \\
\hline $\begin{array}{c}\text { Karanj Cake } 4 \text { q/ha } \\
\left(T_{5}\right)\end{array}$ & 59.40 & 68.40 & 41.20 & 44.00 & 231.60 & 238.40 & 548.00 & 598.00 & 8.20 & 8.50 & 82.00 & 85.00 \\
\hline $\begin{array}{c}\text { Karanj Cake } 6 \text { q/ha } \\
\left(\mathrm{T}_{6}\right)\end{array}$ & 55.20 & 60.00 & 38.00 & 40.80 & 226.40 & 229.60 & 505.60 & 553.60 & 8.75 & 9.10 & 87.50 & 91.00 \\
\hline $\begin{array}{c}\text { Mustard Cake } 2 \text { q/ha } \\
\left(\mathbf{T}_{7}\right)\end{array}$ & 76.40 & 84.00 & 49.60 & 52.80 & 243.00 & 258.00 & 643.40 & 718.00 & 6.53 & 6.75 & 65.30 & 67.50 \\
\hline $\begin{array}{c}\text { Mustard Cake } 4 \mathrm{q} / \mathrm{ha} \\
\left(\mathrm{T}_{8}\right)\end{array}$ & 68.20 & 74.60 & 44.20 & 48.60 & 239.00 & 249.40 & 588.00 & 663.00 & 7.50 & 7.60 & 75.00 & 76.00 \\
\hline $\begin{array}{c}\text { Mustard Cake } 6 \mathrm{q} / \mathrm{ha} \\
\left(\mathrm{T}_{9}\right)\end{array}$ & 60.80 & 65.80 & 41.60 & 43.20 & 234.60 & 240.00 & 545.40 & 588.00 & 8.00 & 8.38 & 80.00 & 83.80 \\
\hline $\begin{array}{c}\text { Carbofuran } 2 \mathrm{~kg} \text { a.i./ha } \\
\left(\mathrm{T}_{10}\right)\end{array}$ & 46.40 & 49.60 & 27.80 & 30.00 & 195.00 & 204.00 & 411.60 & 430.60 & 8.50 & 8.80 & 85.00 & 88.00 \\
\hline $\begin{array}{c}\text { Untreated control } \\
\left(\mathbf{T}_{11}\right)\end{array}$ & 85.00 & 95.80 & 57.60 & 61.20 & 248.40 & 266.00 & 736.00 & 830.00 & 5.70 & 6.10 & 57.00 & 61.00 \\
\hline SEm \pm & 1.731 & 1.806 & 0.968 & 0.918 & 4.885 & 3.318 & 15.641 & 15.828 & - & - & 2.484 & 2.247 \\
\hline CD at $5 \%$ & 4.947 & 5.162 & 2.767 & 2.625 & 13.961 & 9.483 & 44.707 & 45.240 & - & - & 7.099 & 6.422 \\
\hline
\end{tabular}


Table.2 Per cent changes in root-knot nematode parameters and yield of okra through soil amendment with oil-cakes

\begin{tabular}{|c|c|c|c|c|c|c|c|c|c|c|}
\hline \multirow{3}{*}{ Treatments } & \multicolumn{8}{|c|}{ Per cent decrease over control } & \multirow{2}{*}{\multicolumn{2}{|c|}{$\begin{array}{l}\text { Yield increase } \\
\text { over control } \\
(\%)\end{array}$}} \\
\hline & \multicolumn{2}{|c|}{ Galls/ plant } & \multicolumn{2}{|c|}{ Egg masses/plant } & \multicolumn{2}{|c|}{$\begin{array}{c}\text { Eggs and larvae/ } \\
\text { egg mass }\end{array}$} & \multicolumn{2}{|c|}{$\begin{array}{c}\text { Final } \\
\text { nematode } \\
\text { population/100 cc soil }\end{array}$} & & \\
\hline & I year & II year & I year & II year & I year & II year & I year & II year & I year & II year \\
\hline $\begin{array}{c}\text { Neem Cake } 2 \text { q/ha } \\
\left(T_{1}\right)\end{array}$ & 21.88 & 22.13 & 28.47 & 26.80 & 5.15 & 7.52 & 25.52 & 26.75 & 26.32 & 20.98 \\
\hline $\begin{array}{c}\text { Neem Cake } 4 \text { q/ha } \\
\left(T_{2}\right)\end{array}$ & 33.18 & 32.99 & 34.38 & 35.62 & 8.21 & 12.56 & 31.79 & 35.71 & 38.95 & 34.92 \\
\hline $\begin{array}{c}\text { Neem Cake } 6 q / h a \\
\left(T_{3}\right)\end{array}$ & 39.29 & 39.46 & 44.79 & 44.44 & 12.64 & 16.39 & 41.90 & 44.80 & 45.61 & 40.98 \\
\hline $\begin{array}{c}\text { Karanj Cake } 2 \text { q/ha } \\
\left(\mathbf{T}_{4}\right)\end{array}$ & 20.00 & 20.46 & 21.88 & 19.61 & 4.19 & 6.02 & 18.07 & 19.42 & 34.21 & 28.20 \\
\hline $\begin{array}{c}\text { Karanj Cake } 4 \text { q/ha } \\
\left(T_{5}\right)\end{array}$ & 30.12 & 28.60 & 28.47 & 28.10 & 6.76 & 10.38 & 25.54 & 27.95 & 43.86 & 39.34 \\
\hline $\begin{array}{c}\text { Karanj Cake } 6 \text { q/ha } \\
\left(\mathrm{T}_{6}\right)\end{array}$ & 35.06 & 37.37 & 34.03 & 33.33 & 8.86 & 13.68 & 31.30 & 33.30 & 53.51 & 49.18 \\
\hline $\begin{array}{c}\text { Mustard Cake } 2 \text { q/ha } \\
\left(\mathbf{T}_{7}\right)\end{array}$ & 10.12 & 12.32 & 13.89 & 13.73 & 2.17 & 3.01 & 12.58 & 13.49 & 14.56 & 10.66 \\
\hline $\begin{array}{c}\text { Mustard Cake } 4 \text { q/ha } \\
\left(T_{8}\right)\end{array}$ & 19.76 & 22.13 & 23.26 & 20.59 & 3.78 & 6.24 & 20.11 & 20.12 & 31.58 & 24.59 \\
\hline $\begin{array}{c}\text { Mustard Cake } 6 \text { q/ha } \\
\left(\mathbf{T}_{9}\right)\end{array}$ & 28.47 & 31.32 & 27.78 & 29.41 & 5.56 & 9.77 & 25.90 & 29.16 & 40.35 & 37.38 \\
\hline $\begin{array}{c}\text { Carbofuran } 2 \mathrm{~kg} \text { a.i./ha } \\
\left(\mathrm{T}_{10}\right)\end{array}$ & 45.41 & 48.23 & 51.74 & 50.98 & 21.50 & 23.31 & 44.08 & 48.12 & 49.12 & 44.26 \\
\hline $\begin{array}{c}\text { Untreated control } \\
\left(\mathbf{T}_{11}\right)\end{array}$ & - & - & - & - & - & - & - & - & - & - \\
\hline
\end{tabular}


These treatments significantly reduced the number of galls and egg masses per plant. The most effective treatment was neem cake followed by mustard cake.

The suppression of nematodes in amended soil may be because of the effect of several combined factors. Production of volatile fatty acids, phenols, ammonia, amino acids etc. during decomposition of oil-cakes may cause inhibitory effect to the nematodes or the decomposed products may be directly toxic to nematodes or the microbial metabolites produced during decomposition may be toxic to nematodes or enhance activity of predators and parasites which may attack the nematodes causing reduction in their population. In present investigation also root-knot nematode, $M$. incognita produced less number of galls, egg masses, eggs and larvae/egg mass and final nematode population under oil-cake treatments over untreated control which is in accordance with the findings of the previous workers.

Results pertaining to yield revealed that neem, karanj and mustard cakes when applied @ 2, 4 and $6 \mathrm{q} / \mathrm{ha}$ as soil amendment in root-knot nematode, $M$. incognita infested field significantly enhanced the okra yield over untreated control. Among different oil-cake treatments, maximum yield (87.50 and 91.00 $\mathrm{q} / \mathrm{ha}$ ) was recorded with the application of karanj cake @ 6 q/ha followed by neem cake @ 6 q/ha (83.00 and 86.00 q/ha), karanj cake @ $4 \mathrm{q} / \mathrm{ha}(82.00$ and $85.00 \mathrm{q} / \mathrm{ha})$ and mustard cake @6 q/ha (80.00 and 83.80 q/ha) while it was obtained 57.00 and $61.00 \mathrm{q} / \mathrm{ha}$ in untreated control during I and II year, respectively. Per cent yield increase over control was calculated with the application of different oil-cake treatments and it was maximum (53.51 and $49.18 \%$ ) with karnaj cake@6 q/ha followed by neem cake @6 q/ha (45.61 and 40.98\%), karanj cake @ 4 q/ha (43.86 and $39.34 \%$ ) and mustard cake @
6 q/ha (40.35 and $37.38 \%$ ) during I and II year, respectively. These results are similar to the findings of Singh (1965), Goswami and Swarup (1971), Goswami et al., (1988), Govindaiah et al., (1989), Ajith and Sheela (1996), Ramkrishnan et al., (1997), Randhawa et al., (2002), Baheti et al., (2015) and Resha and Rani (2015).

Efficacy of karanj cake (Pongamia glabra) was reported by Singh (1965) to reduce rootknot nematode infection and enhance yield of tomato. Goswami and Swarup (1971) reported that karanj and groundnut cakes significantly improved growth of tomato against root-knot nematode, $M$. incognita. Goswami et al., (1988) found that karanj cake was most effective for control of root-knot nematode, $M$. incognita and subsequently increased yield of cowpea.

Govindaiah et al., (1989) reported that mulching of green leaves of pongamia and neem in the soil has significantly increased the plant growth as well as leaf yield of mulberry and reduced the infection of $M$. incognita. However, mulching of pongamia leaves was found to be superior over neem leaves. Randhawa et al., (2002) observed that soil amendment with neem cake significantly increased okra yield. These findings supports that application of oil-cakes as soil amendment enhanced plant growth and crop yield in nematode prone areas.

This might be due to the fact that soil amendment with oil-cakes improve physical condition of soil, reduce population of plant parasitic nematode, enhances the activity of beneficial soil microbes. However, different oil-cakes exert different reactions with respect to plant growth parameters. This may be perhaps due to variation in their nematicidal value, soil and environmental conditions, nematode species, initial nematode population, crop and its variety etc. 


\section{Acknowledgement}

The authors are highly grateful to the Head, Department of Nematology, Rajasthan College of Agriculture, MPUAT, Udaipur (Raj) for providing necessary facilities and critically reviewed the article.

\section{References}

Ajith, K. and Sheela, M.S. 1996. Utilization of green leaves of neem and eupatorium for management of soil organisms in bhindi and cowpea. Indian J. Nematol. 26(2): 139-143.

Anonymous, 2018-19a. Final area and production estimates for Horticulture Crops for (2018-19), National Horticulture Board, Ministry of Agriculture and Cooperation, Government of India, New Delhi, India

Anonymous, 2018-19b. Area and production estimates for Horticulture Crops for (2018-19), Directorate of Horticulture, Government of Rajasthan, Jaipur, India.

Arya, H.C., 1957. Root-knot diseases of tomatoes in Jodhpur. Science and Culture 22: 391-393.

Baheti, B. L., Dodwadiya Mukesh, Rathore, B. S. and Bhati, S. S., 2015. Management of maize cyst nematode, Heterodera zeae on sweet corn (Zea mays L. saccharata) through soil amendment. The Ecoscan, 7(1): 305-309.

Baheti, B. L. and Bhati, S. S., 2017. Estimation of Losses Caused by Root-Knot Nematode, Meloidogyne incognita in Varied Soil Conditions on Okra (Abelmoschus esculentus L.). Current Nematology, 28(2): 201-207.

Barber, C.A., 1901. A tea eel worm disease in South India. Department of Land Records, Madras Agricultural Branch, II. Bull. No. 45: 227-234.

Bhatti, D.S. and Jain, R.K., 1977. Estimation of losses in okra, tomato and brinjal yield due to Meloidogyne incognita. Indian Journal of Nematology7: 37-41.
Devi Sunita and Das Debanand, 2016. Effect of organic amendments on root-knot nematode (Meloidogyne incognita) in cucumber. Pest Management in Horticultural Ecosystems, 22(2): 176181.

Goswami, B.K. and Singh, S., 1998. Efficacy of some soil mycoflora arising from the oilseed cakes of cotton seed, karanj, mahua and mustard amended soil against Meloidogyne incognita infecting okra. Ann. Agric. Res. 19(2): 158-161.

Goswami, B.K. and Swarup, G., 1971. Effect of oil-cake amended soil on tomato growth and root-knot population. Indian Phytopath. 24: 491.

Goswami, B.K., Haque, M.M., Mishra, S.D. and Mojumder, V., 1988. Comparative efficacy of Hind-O-Meal, Karanj, castor oilseed cakes and carbofuran against root-knot nematode in cowpea. Ann. Agril. Res. 10(3): 316-318.

Govindaiah, Suryanarayan, N., Sharma, D.D. and Gargi, 1989. Effect of mulching of green leaves for the control of root-knot nematode in mulberry. Indian $J$. Nematol. 19(1): 25-28.

Mahajan, R. and Kaur, D., 1991. Status of plant parasitic nematodes in Punjab, India. Current Nematology 2: 177-182.

Muhammad, S, Riaz, A., Khan, H. U. and Rehman, A.U., 2001. Comparative efficacy of different organic amendments in the control of root-knot nematode, Meloidogyne incognita in mungbean. Pakistan J. Phytopath 13(1): 12-14.

Parihar K, Rehman B, Ganai MA, Asif M, Siddiqui Mansoor A., 2015. Role of Oil Cakes and Pochonia chlamydosporia for the Management of Meloidogyne javanica Attacking Solanum melongena L. J Plant Pathol Microbiol S1: 004. doi:10.4172/2157-7471.S1-004

Parvatha Reddy, P. 1986. Analysis of crop losses in vegetables due to $M$. incognita. Intl. Nematol. Network Newsl. 3(4): 3-5.

Parvatha Reddy, P. and Singh, D.B., 1981. Assessment of avoidable yield losses in 
okra, brinjal, French bean and cowpea due to root-knot nematode. III International Symposium of Plant Pathology, New Delhi. Pp. 93-94.

Patel, H.R., Patel, B.A., Vyas, R.V. and Patel, D.J., 1998. Organic amendments in management of root-knot nematodes in bottle gourd. In: Proc. Nat. Sym. on "Rational approaches in nematode management for sustainable agriculture" held from 23-25 November, 1998 at GAU, Anand, India. Pp. 7-9.

Prasad, S.K., 1960. Plant parasitic nematodes observed at the Indian Agricultural Research Institute Farm. Indian Journal of Entomology 22: 127-128.

Ramkrishanan, S., Gunasekaran, C.R. and Vadivelu, S., 1997. Efficacy of organics in control of Meloidogyne incognita on okra. Indian J. Nematol. 27(1): 74-78.

Randhawa, N., Sakhuja, P.K. and Singh, I., 2002. Management of root-knot nematode, Meloidogyne incognita in Abelmoschus esculentus through botanical extracts and organic amendments. Indian J. Nematol. 32(2): 129-131.

Ravichandra, N.G. and Krishnappa, K., 2004. Prevalence and distribution of phytoparasitic nematodes associated with major vegetable crops in Mandya district, Karnataka. Indian Journal of Nematology 34: 113-116.

Resha and Rani, S., 2015. Management of root Knot Nematode (Meloidogyne Incognita) using Neem (Azadiractha Indica).Journal of Environmental Science, Toxicology and Food Technology 9(3): 12-15.

Sahu Sasmita, Patra M. K. and Dash B., 2018.
Management of Root Knot Nematode (Meloidogyne incognita) in Tomato using Different Oil Cakes. Int.J.Curr.Microbiol.App.Sci. $\quad 7(03)$ : 2527-2532.

Sharma, G. L. and Baheti, B. L., 1992. Loss estimates due to root-knot nematode in pea, okra, tomato and bottle gourd crops in Rajasthan, India. Current Nematology 3:187-188.

Singh, R. J., 1965. Control of root-knot nematode of tomato with organic soil amendments. FAO Plant Protection Bulletin 13:35-37.

Singh, R.S. and Sitaramaiah, K., 1970. Control of plant parasitic nematodes with organic soil amendments. PANS, 16: 287-297.

Srivastava, A.S., Pandey, R.C. and Ram, S., 1971. Application of organic amendments for the control of root-knot nematode, Meloidogyne javanica. Labdev. J. Sci. Tech. 98: 203-205.

Srivastava, D. S., Sehgal, M., Kumar, A., Verma, S., Dwivedi, B. K. and Singh, S. P., 2012. Plant parasitic nematodes associated with tomato and okra fields of Allahabad, Uttar Pradesh, India. Pakistan Journal of Nematology 30: 157-167.

Thakur, S.G. and Darekar, K.S., 1995. Effect of some non-edible oilseed cakes against root-knot nematode, Meloidogyne incognita and growth parameters of brinjal. Curr. Nematol. 6(1): 21-26.

Yadav, B.S., Verma, A.C., Mathur, B.N. and Varma, M.K., 1969. Nematodes of cereals and vegetables grown in Rajasthan. All India Nematol. Symp., IARI, New Delhi. Pp. 21-22.

\section{How to cite this article:}

Baheti, B. L., S. S. Bhati and Hanuman Singh. 2019. Efficacy of Different Oil-Cakes as Soil Amendment for the Management of Root-knot Nematode, Meloidogyne incognita Infecting Okra (Abelmoschus esculentus L.). Int.J.Curr.Microbiol.App.Sci. 8(12): 799-808. doi: https://doi.org/10.20546/ijcmas.2019.812.104 